\title{
TOTAL PHENOLIC AND FLAVONOID CONTENTS AND ANTIOXIDANT ACTIVITY OF ETHANOL FRACTION OF PICRIA FEL-TERRAE (LOUR.) HERBS
}

\section{PANAL SITORUS ${ }^{1 *}$, POPPY ANJELISA ZAITUN HASIBUAN ${ }^{2}$, DENNY SATRIA ${ }^{1}$}

${ }^{1}$ Department of Pharmaceutical Biology, Faculty of Pharmacy, University of Sumatera Utara, Indonesia. ${ }^{2}$ Department of Pharmacology, Faculty of Pharmacy, University of Sumatera Utara, Indonesia. Email: sitoruspanal@gmail.com

Received: 18 February 2017, Revised and Accepted: 12 April 2017

\section{ABSTRACT}

Objective: To evaluate total phenolic, flavonoid content (TFC and TPC) andantioxidant activity of ethyl acetate fraction (ETF) of Picria fel-terrae Lour. herbs.

Methods: TPC and TFC in ETF were determined by Folin-Ciocalteu and colorimetric methods, and antioxidant activity was determined by 1,1-diphenyl2-picrylhydrazyl (DPPH) method.

Results: ETF was found to contain low levels of phenolic (17.71 $\pm 1.26 \mathrm{mg}$ gallic acid equivalent/g), total flavonoid (14.43 $\pm 0.03 \mathrm{mg}$ quercetin equivalents/g). Antioxidant activity from DPPH assay was measured as inhibitory concentration $25.72 \pm 0.13 \mu \mathrm{g} / \mathrm{mL}$.

Conclusions: The results reveal that ETF of $P$. fel-terrae Lour. herbs has strong antioxidant activity. Our further study is to the isolation of compounds which responsible for antioxidant components.

Keywords: Phenolic, Flavonoid, Antioxidant, P. fel-terrae Lour., Ethanol, Herbs.

(C) 2017 The Authors. Published by Innovare Academic Sciences Pvt Ltd. This is an open access article under the CC BY license (http://creativecommons. org/licenses/by/4. 0/) DOI: http://dx.doi.org/10.22159/ajpcr.2017.v10i7.17982

\section{INTRODUCTION}

Free radicals are arising from metabolism process or environmental sources which interact simultaneously with the biological system. Reactive species are molecules or atoms that have an electronic stability and most reactive. Reactive oxygen species (ROS) are main sources of a primary catalyst which initiate the process of oxidation in vivo and in vitro and create oxidative stress. Oxidative stress products when reactive forms of oxygen are produced faster than they could be safely neutralized by antioxidant mechanisms and/or from a decrease in antioxidant defense. The uncontrolled production of oxygen free radicals and the undateables system of antioxidant protection results in the cause of many diseases, such as cancer, diabetes, heart diseases, Alzheimer's, and aging [1-6].

Antioxidants are the material when them present in low concentrations compared to those of an oxidizable substrate significantly defers or avoids oxidation of that substances ethnopharmacological studies conducted and expressed that a large number of indigenous plant species are being used as a source of herbal therapies $[7,8]$.

Poguntano (Picria fel-terrae Lour.) have been used as a drug of colic, malaria, diuretic, fever, and skin disease [9]. Modern pharmacological investigations indicated that the extract of $P$. fel-terrae Lour. exerts diuretic, antipyretic, hepatoprotective, cardioprotective, antidiabetic, antioxidant, anti-inflammatory, anthelmintic, anti-asthma, and analgesic activities [10-19]. Moreover, P. fel-terrae inhibit hepatitis B (HB) e-antigen excreted by HepG2 2215 cell lines, suggesting to have anti-HB virus activity [20]. It can be developed as a co-chemotherapeutic regimen for breast cancer by inducing apoptosis and cell cycle arrest and suppressing cyclin D1 and Bcl-2 expression based on the recent studies [21,22]. In in silico analysis Picfeltarraenin IA and IB as potential PI3K and epidermal growth factor receptor inhibitor [23]. The aim of this study was to determine total phenolic and flavonoid content (TPC and TFC) and antioxidant activity of ethanol fraction of P. fel-terrae Lour. herbs.

\section{METHODS}

Plant and chemicals material

Fresh herbs of P. fel-terrae Lour. were collected from Tiga Lingga village, Dairi regency, Sumatera Utara province, Indonesia. Chemicals used were $\mathrm{AlCl}_{3} \cdot 6 \mathrm{H}_{2} \mathrm{O}$ (Merck), distilled water, 1,1-diphenyl-2-picrylhydrazyl (DPPH) (Sigma), Folin-Ciocalteu (Sigma), gallic acid (Sigma), Quercetin (Sigma), sodium acetate (Merck), and sodium bicarbonate (Merck).

\section{Preparation of ethyl acetate fraction (ETF)}

The air-dried and powdered herbs of $P$. fel-terrae Lour. $(1 \mathrm{~kg})$ were repeatedly fractionated by maceration with $n$-hexane $(3 \times 3$ day, $7.5 \mathrm{~L})$, the powder was dried in the air and fractionated with ethyl acetate $(3 \times 3$ day, $7.5 \mathrm{~L})$, the powder was dried in the air and fractionated with ethanol $(3 \times 3 \mathrm{~d}, 7.5 \mathrm{~L})$ at $25-30^{\circ} \mathrm{C}$ with periodical stirring. The filtrate was collected, and then evaporated to obtain a viscous fraction and then freeze dried to dry $[7,10,21,24]$.

\section{Determination of total phenol content (TPC)}

The TPC of the sample was determined using Folin reagent. Briefly, $100 \mu \mathrm{L}$ of ETF $(500 \mu \mathrm{g} / \mathrm{mL}$ ) was mixed with $7.9 \mathrm{~mL}$ of distilled water and $0.5 \mathrm{~mL}$ of Folin-Ciocalteu's reagent $(1: 10 \mathrm{v} / \mathrm{v})$ and mixed using vortex for 1 minute. After mixing, $1.5 \mathrm{~mL}$ of $20 \%$ sodium bicarbonate solution was added, and the mixture was incubated for 90 minutes with intermittent shaking. The absorbance was determined at $775 \mathrm{~nm}$ with a spectrophotometer. Total phenolic concentration is interpreted as gallic acid equivalent (GAE) in $\mathrm{mg} / \mathrm{gram}$ of extract. The methanol solution was to use a blank control $[2,5,10,25]$. The equation to determine total phenolic concentration:

$$
\mathrm{C}(\mathrm{GAE})=\frac{\mathrm{c} \times \mathrm{V}}{\mathrm{M}} \times \mathrm{F}
$$

C(GAE): Content of phenolic as GAE, c: Concentration determined from standard curve $(\mu \mathrm{g} / \mathrm{mL}), \mathrm{V}$ : Volume which used in the assay $(\mathrm{mL})$, M: Mass of the sample which used in the assay (g), and F: Dilution factor. 


\section{Determination of TFC}

The amount of total flavonoids in the extracts was determined spectrophotometrically as previously reported. Briefly, $2 \mathrm{~mL}$ of ETF in methanol was mixed with $0.10 \mathrm{~mL}$ of $10 \%$ aluminum chloride $\left(\mathrm{AlCl}_{3} \cdot 6 \mathrm{H}_{2} \mathrm{O}\right), 0.10 \mathrm{~mL}$ of sodium acetate $\left(\mathrm{NaC}_{2} \mathrm{H}_{3} \mathrm{O}_{2} .3 \mathrm{H}_{2} \mathrm{O}\right)(1 \mathrm{M})$ and $2.80 \mathrm{~mL}$ of distilled water. After incubation along 40 minutes, absorbance was measured at $432 \mathrm{~nm}$ with a spectrophotometer. To determine the content of flavonoids, we prepared a calibration curve using quercetin as standard. The flavonoid content is expressed as quercetin equivalents $(\mathrm{QE})$ in $\mathrm{mg} /$ gram of extract $[2,26]$. The equation to determine total flavonoid concentration:

$$
C(Q E)=\frac{c \times V}{M} \times F
$$

$\mathrm{C}(\mathrm{QE})$ : Content of flavonoid as QE, c: Concentration determined from standard curve $(\mu \mathrm{g} / \mathrm{mL}), \mathrm{V}$ : Volume which used in the assay $(\mathrm{mL})$, M: Mass of the sample which used in the assay (g), and F: Dilution factor.

\section{Free radical scavenging activity test}

The DPPH assay was carried out according to the previous study with some modifications [27]. $0.2 \mathrm{mM}$ solution of DPPH• in methanol was prepared, and $100 \mu \mathrm{l}$ of this solution was added to various concentrations of ETF at the concentrations of 12.5, 25, 50, and $100 \mu \mathrm{g} / \mathrm{ml}$. After 60 minutes, absorbance was measured at $516 \mathrm{~nm}$. Quercetin was used as the reference control, and percentage of inhibition was calculated by comparing the absorbance values of the control and test samples $[2,5]$

\section{Percentage of inhibition $=\frac{\text { Abscontrol-Abstest }}{\text { Abscontrol }} \times 100 \%$}

\section{Statistical analysis}

Data were expressed as mean \pm standard deviation, which were analyzed using the SPSS 20 software.

\section{RESULTS AND DISCUSSION}

\section{TPC and TFC}

TPC was determined by the Folin-Ciocalteau method [28]. The ETF of $P$. fel-terrae Lour. herbs was found to contain low levels of phenolic content $17.71 \pm 1.26 \mathrm{mg}$ GAE/g. Phenolic compounds are known as an antioxidant [29], and they are very important plant constituents because of their free radical scavenging ability due to their hydroxyl groups [30].

In the case of TFC, the ETF was given flavonoid content $14.43 \pm 0.03 \mathrm{mgQE} / \mathrm{g}$. Flavonoids are a group of polyphenolic compounds, which exhibit several biological effects such as anti-inflammatory, antihepatotoxic, anti-ulcer, anti-allergic, antiviral, and anti-cancer activities [31]. They are capable of effectively scavenging the ROS because of their phenolic hydroxyl groups, and so they are potent antioxidants also [32].

\section{Antiradical activity}

Antiradical power of the plant samples was measured in term of hydrogen donating ability using DPPH which is a stable, nitrogencentered free radical and produces deep purple color in methanol solution [33]. DPPH test, which is based on the ability of DPPH, a stable free radical, to decolorize in the presence of antioxidants, is a direct and reliable method for determining radical scavenging action [34] and has been largely used as a quick, reliable and reproducible at in vitro antioxidant activity assay [35]. The reducing capacity of compounds could serve as an indicator of potential antioxidant property [36-39]. Inhibitory concentration for ETF and Quercetin in DPPH assay was $25.72 \pm 0.13 \mu \mathrm{g} / \mathrm{mL}$ and $4.94 \pm 0.05 \mu \mathrm{g} / \mathrm{mL}$, respectively.

\section{CONCLUSION}

The result of this study showed that ethanol fraction of $P$. fel-terrae Lour. possess antioxidant activity.

\section{REFERENCES}

1. Kinnula VL, Crapo JD. Superoxide dismutases in malignant cells and human tumors. Free Radic Biol Med 2004;36(6):718-44.

2. Jamuna S, Pulsamy S, Karthika K. Screening of in vitro antioxidant activity of methanolic leaf and root extracts of Hypochaeris radicata $\mathrm{L}$. (Asteraceae). J Appl Pharm Sci 2012;2(7):149-54.

3. Nagmoti DM, Khatri DK, Juvekar PR, Juvekar AR. Antioxidant activity free radical-scavenging potential of Pithecellobium dulce Benth seed extracts. Free Radic Antioxid 2012;2:37-43.

4. Rackova L, Oblozinsky M, Kostalova D, Kettman V, Bezakova L. Free radical scavenging activityand lipoxygenase inhibition of Mahonia aquifolium extract and isoquinoline alkaloids. J Inflam (Lond) 2007;4:15

5. Rosidah, Yam MF, Sadikun A, Asmawi MZ. Antioxidant potential of Gyunura procumbens. Pharm Bio 2008;46(9):616-25.

6. Yang YC, $\mathrm{Lu} \mathrm{FH,} \mathrm{Wu} \mathrm{JS,} \mathrm{Wu} \mathrm{CH,} \mathrm{Chang} \mathrm{CJ.} \mathrm{The} \mathrm{protective} \mathrm{effect}$ of habitual tea consumption on hypertension. Arch Intern Med 2004;164(14):1534-40.

7. Anggraeni R, Hadisahputra S, Silalahi J, Satria D. Combinational effects of ethylacetate extract of Zanthoxylum acanthopodium DC. With doxorubicin on T47D breast cancer cells. Int J PharmTech Res 2014;6(7):2032-5.

8. Barnett GC, Shah M, Redman K, Easton DF, Ponder BA, Pharoah PD. Risk factors for the incidence of breast cancer: Do they affect survival from the disease? J Clin Oncol 2008;26(20):3310-6.

9. Perry LM. Medicinal Plants of East and Southeast Asia. London: The MIT Press; 1980

10. Dalimunthe A, Urip H, Rosidah, Pandapotan NM. Evaluation of diuretic activity of Picria fel-terrae (Lour.) Leaves extracts. Asian J Pharm Clin Res 2015;8(4):204-5.

11. Huang Y, Cimanga K, Lasure A, Van Poel B, Pieters L, BergheVanden D. Biological activities of Picria fel-terrae Lour. Pharm World Sci 1994;16(6): 18

12. Thuan ND, Ha do T, Thuong PT, Na MK, Lee JP, Lee JH, et al. A phenylpropanoid glycoside with antioxidant activity from Picria telferae. Arch Pharm Res 2007;30(9):1062-6.

13. Zhong SQ, Zhang BN, Huang FX. An anti-tumor herb Cucao. China: ChinaTraditionally Herb Drugs Letter; 1979.

14. Zou JM, Wang LS, Niu XM, Sun HD, Guo YJ. Phenylethanoid glycosides from Picria felterrae Lour. J Integ Plant Bio 2005;47:632-6.

15. Harfina F, Bahri S, Saragih A. Pengaruh serbuk daun puguntano (Curanga fel-terrae Merr.) Pada pasien diabetes mellitus. J Pharm Pharmacol 2012;1(2):112-8.

16. Sitorus $P$, Harahap U, Pandapotan $M$, Barus T. Isolation of $\beta$-sitosterol from n-hexane of Picria fel-terrae Lour. Leave and study of its antidiabetic effect in alloxan induced diabetic mice. Int $\mathrm{J}$ Pharmtech Res 2014;6(1):137-41.

17. Sihotang YM, Silalahi J, Hadisahputra H, Hasibuan PA, Satria D. Cardioprotective effect of ethylacetate extract of poguntano (Picria felterrae Lour.) Against doxorubicin-induced cardiotoxicity in rats. Int $\mathrm{J}$ Pharm Clin Res 2016;8:466-70.

18. Patilaya P, Dadang IH. Preliminary study on the anthelmintic activity of the leaf ethanolic extract of Indonesian Curanga fel-terrae (Lour.) Merr. Int J Pharmtech Res 2015;8(3):347-51.

19. Harahap U, Husori DI, Marianne, Yuliasmi S, Patilaya P, Laila L, et al. Inhibitory effect of ethanolic extract of Curanga fel-terrae (pugun tano) leaves on acetylcholine muscarinic-3 receptors induced on isolated guinea pig tracheal. Asian J Pharm Clin Res 2017;10(1):95-8.

20. Zeng J, Pan X, Yang K, Wei Z, Chen C. Experimental study on the inhibitory effect on HbeAg and HbsAg excreted by 2215 cells of different extracts of Picria fel-terrae Lour. Chin Med Her 2010;7:27-9.

21. Satria D, Furqan M, Hadisahputra S, Rosidah. Combinational effects of ethylacetate extract of Picria fel-terrae Lour. And doxorubicin on T47D breast cancer cells. Int J Pharm Pharm Sci 2015;7:73-6.

22. Lestari P. Combination effect of active extract from Picria fel-terrae Lour.) With doxorubicin against breast cancer cells. Thesis. Medan. Faculty of Pharmacy. University of Sumatera Utara; 2013.

23. Hasibuan, PA, Denny S, Urip H, Jansen S. In silico analysis of Picfeltarraenin IA and IB as potential PI3K and EGFR inhibitor. Pharm Chem 2016;8(19):666-70.

24. Hasibuan PA, Jessy C, Denny S. Combination effect of ethylacetate extracts of Plectranthus ambonicius (Lour.) Spreng. With doxorubicin againts T47D breast cancer cells. Int J Pharm Pharm Sci 2015;7(10):155-9

25. Settharaksa S, Madaka F, Chakree K, Charoenchai L. Total phenolic and flavonoid contents and antioxidant properties of Thai traditional 
herbal. Int J Pharm Pharm Sci 2014;6(9):564-6.

26. Diab KA, Shafik RE, Yasuda S. In vitro antioxidant and antiproliferative activities of novel orange peel extract and it's fractions on leukemia HL-60 cells. Asian Pac J Cancer Prev 2015;16(16):7053-60.

27. Jebitta R, Allwin J. Antioxidant activity, total phenolic, flavonoid, and anthocyanin contents of Jamun (Syzygium cumini) pulp powder. Asian J Pharm Clin Res 2016;9:361-3.

28. Cicco N, Lanorte MT, Paraggio M, Viggianoa M, Lattanzio V. A reproducible, rapid, and inexpensive folin-ciocalteu micro-method in determining phenolies of plant methanol extracts. Microchem J 2009;91(1):107-10.

29. Shahidi F, Wanasundara PK. Phenolic antioxidants. Crit Rev Food Sci Nutr 1992;32(1):67-103

30. Hatano T, Edamatsu R, Mori A. Effect of interaction of tannins and related poyphenols on superoxide anion radical and on DPPH radical. Chem Pharm Bull 1989;37:2016-21.

31. Umamaheswari M, Chatterjee TK. In vitro antioxidant activities of the fractions of Coccinia grandis L. Leaf extract. Afr J Tradit Complement Altern Med 2007;5(1):61-73.

32. Cao G, Sofic E, Prior RL. Antioxidant and pro-oxidative behavior of flavonoids: Structure activity relationships. Free Radic Biol Med 1997;22(5):749-60.
33. Pan Y, Wang K, Huang S, Wang $\mathrm{H}, \mathrm{Mu} \mathrm{X}, \mathrm{He} \mathrm{C}$, et al. Antioxidant activity of microwave-assisted extract of longan (Dimocarpus longum Lour.) Peel. Food Chem 2008;106(3):1264-70.

34. Hasan MS, Ahmed MI, Mondal S, Uddin SJ, Masud MM, Sadhu SK, et al. Antioxidant, antinociceptive activity and general toxicity study of Dendrophthoe falcata and isolation of quercitin as the major component. Orient Pharm Exp Med 2006;6(4):355-60.

35. Koleva II, van Beek TA, Linssen JP, de Groot A, Evstatieva LN. Screening of plant extracts for antioxidant activity: A comparative study on three testing methods. Phytochem Anal 2002;13(1):8-17.

36. Meir S, Kanner J, Akiri B, Hada SP. Determination and involvement of aqueous reducing compounds in oxidative defense system of various senescing leaf. J Agric Food Chem 1995;43(7):1813-9.

37. Dalimunthe A, Achmad S, Satria D. Phenolic, flavonoid content and antioxidant activities of ethylacetate extract of Litsea cubeba (Lour.) Pers. Barks. Pharm Chem 2016;8(19):466-8.

38. Shah A, Singh T, Rekha V. In vitro antioxidant properties and total phenolic and flavonoid contents of Rumex vesicaius L. Int J Pharm Pharm Sci 2015;7(7):81-4.

39. Satria D, Silalahi J, Haro G, Ilyas S, Hasibuan PA. Antioxidant and antiproliferative activities of an ethylacetate fraction of Picria fel-terrae Lour. Herbs. Asian Pac J Cancer Prev 2017;18(2):399-403. 